DOI https://doi.org/10.18551/rjoas.2018-02.05

\title{
THE ROLE OF ORGANIZATIONAL COMMITMENT MEDIATION ON THE EFFECT OF PERSON-ORGANIZATION FIT AND JOB SATISFACTION TO TURNOVER INTENTION
}

\author{
Risma Nuansa*, Asmony Thatok, Nurmayanti Siti \\ University of Mataram, Indonesia \\ *E-mail: nuansarisma@gmail.com
}

\begin{abstract}
This study aimed to analyze and find out the role of organizational commitment mediation on the effect of person-organization fit and job satisfaction to the turnover intention of marketing funding employees. The research method used was quantitative. The type of this research was causal associative by using purposive sampling method in the sample determination. Respondents are 96 employees of Marketing Funding at Bank Nusa Tenggara Barat, Indonesia. The data analysis technique used was Partial Least Square analysis. The research result showed that person-organization fit has no significant effect on turnover intention, job satisfaction has no significant effect on turnover intention, person-organization fit has significant effect on the organizational commitment, job satisfaction has significant effect on organizational commitment, organizational commitment has significant effect on turnover intention, organizational commitment fully mediates the relationship between person-organization fit on turnover intention, and organizational commitment fully mediates the relationship between job satisfaction on turnover intention.
\end{abstract}

\section{KEY WORDS}

Person-organization fit, job satisfaction, organizational commitment, turnover intention, bank.

Human resources are the most important asset in a company. The management of the company's human resources must be able to run in order for the company to compete with other companies. Conversely, if the management of human resource of a company is not running effectively, then various problems that disrupt the performance of the company will occur. One of the employee behaviors that often arises due to the failure of the company to manage its human resource is a desire to switch jobs (turnover intention) that lead to the employees' decision to leave their job. Based on the 2015 Salary Survey conducted by Mercer Talent Consulting \& Information Solution, the global HR consulting company that is the partner of SWA, the turnover rate of all industries is still high at $8.4 \%$. The highest turnover rate occurred in the banking sector, at $16 \%$. Of course, the high turnover rate can disrupt the activities and productivity of a company. Many things can cause turnover intention; among others is the suitability of individuals with the organization, work environment, job satisfaction, organizational commitment, and so forth.

Mobley (1986) states that turnover intention is defined as the tendency or intention of an employee to quit his/her job voluntarily or to switch from one workplace to another according to his/her own choice. Meanwhile, turnover according to Robbins and Judge (2009) is the act of permanent resignation made by employees either voluntarily or not. One of the employees with high turnover intensity is the marketing funding department. The Marketing funding employees at PT. Bank NTB, which is a local government bank of Nusa Tenggara Barat (NTB), has a low turnover rate from January 2016 to January 2017 at $2 \%$. According to Roseman (1981), the turnover rate above $10 \%$ per year is classified as the high turnover rate. The phenomenon of the low turnover rate of marketing funding employees at PT. Bank NTB is inversely proportional to the global survey showing high turnover rates. Therefore, this research was conducted to find out and analyze the role of organizational commitment mediation on the effect of person-organization fit and job satisfaction to turnover intention on marketing funding employees at PT. Bank NTB. 


\section{LITERATURE REVIEW}

Person-Organization Fit. According to a view by Kristof-Brown et al., (2005), the person-organization fit is a suitability between employees and organization that occur when there are entities that provide what is needed by both parties or have similarities related to fundamental characteristics. Meanwhile, Donald and Pandey (2007) have another view on person-organization fit, that is the fit/suitability between individuals when: (1) there is at least a sincerity to meet the needs of others, or (2) they have similar basic characteristics. Kristof (1996) divides person-organization fit into four aspects: value fit, objectivity fit, fulfillment of the employee needs, and characters fit of culture-personality.

Research conducted by Liu et al., (2010) in the Chinese Public Sector indicates that person-organization fit negatively affects turnover intention. Subsequent research by Hassan (2012) conducted on five of the best commercial banks in the city of Pakistan shows that person-organization fit negatively and significantly affects turnover intention. This shows that the higher the person-organization fit of employees, the lower the desire to leave the organization. The different results of studies are shown by Latif and Bashir (2013) with positive and insignificant results between person-organization fit and turnover intention relationships. This research suggests that employees will not leave the organization merely because of a value discrepancy with the company.

Job Satisfaction. Robbins (2007) says that job satisfaction is an individual's general attitude towards his/her work. Jobs demand interaction with colleagues, employers, organizational rules and policies, performance standards, working conditions and so on. A person with a high level of job satisfaction shows a positive attitude towards the work, on the contrary, a person that is not satisfied with his/work showing a negative attitude towards the work. Job satisfaction according to Roelen (2008) is measured using five indicators, namely satisfaction with the job itself, satisfaction with salary, satisfaction with the attitude of superior, satisfaction with co-worker, and satisfaction with the promotion.

Mobley et al., (1978) states that job satisfaction has a close relationship to employee turnover intention which followed by the search for another job. Similarly, Motowildo (1983), expresses that job satisfaction affects employee turnover intention and this is the result of the expectations of employees to their current work. Subsequent research by Tnay et al. (2013) shows the result that there is a negative effect of job satisfaction on turnover intention, organizational commitment negatively affects turnover intention. This study is in line with research by Ghandi et al. (2017) which states that job satisfaction negatively and significantly affects the turnover intention. Similarly, research conducted by Sutanto and Gunawan (2013) shows that job satisfaction also has a positive effect on organizational commitment. This research is supported by research conducted by Yamazakia and Petchdee (2015) which shows that job satisfaction is very important because it contributes to the success of the company through its human resources, among others, increasing their organizational commitment. Similarly, research conducted by Octaviani (2015) shows insignificant results on the relationship of job satisfaction and turnover intention.

Organizational Commitment. According to Mowday et al., (1982) organizational commitment can be seen in the employees who serve the organization according to their job and work wholeheartedly for the benefit of the organization and they will maintain their membership in the organization. Meyer and Allen (1991) explain that there are three dimensions of organizational commitment, namely (1) affective commitment refers to the emotional attachment, identification and involvement of an employee in an organization, (2) continuance commitment related to the concept of side-bets orientation that emphasizes the contribution of a person which may at times be lost if the person leaves the organization and (3) the normative commitment shows how far a person is psychologically bound to be an employee of an organization based on feelings such as loyalty, affection, warmth, possessiveness, pride, happiness, etc.

A study by Ahmadi et al. (2014) on employees in the City of Tehran shows that personorganization fit positively and significantly affects organizational commitment. Further research by Khaola and Sebotsa (2015) shows a positive and significant relationship 
between person-organization fit and organizational commitment. Further research conducted by Saeka and Suana (2016) shows organizational commitment negatively affects turnover intention. This means that higher organizational commitment on each employee will reduce the turnover intention rate. Research by Jehanzeb et al., (2013) states that organizational commitment negatively and significantly affects turnover intention.

Turnover Intention. Robbins (2006) explains that a person's withdrawal from an organization (turnover) can be decided in two ways: (1) voluntary turnover is the employee's decision to leave the organization voluntarily, (2) involuntary turnover, describes the employer's decision to terminate the employment relationship and is uncontrollable to the employee who experiences it. According to Saeed et al. (2014), the turnover intention is a condition in which an organization's employees have plans to leave their jobs. Booth and Hamer (2007) define turnover intention as the worst impact of an organization's inability to manage individual behavior so that individuals feel they have higher job change intentions. According to Mobley et al., (1978) the indicator of turnover intention measurements consist of thinking to quit, searching for alternative employment, and intention to quit.

Subsequent research by Alniacik et al., (2013) and Faloye (2014) shows no influence between organizational commitment and turnover intention. This means that, in this study, organizational commitment as a mediation variable has no significant relationship to turnover intention.

\section{METHODS OF RESEARCH}

The research method used was quantitative. Type of research used was associative causal to find out the effect of the independent variable to dependent variable. This research was conducted at PT. Bank NTB with respondents of marketing funding employees as many as 96 people. The questionnaires were distributed as many as 96 questionnaires and then all the questionnaires were processed to obtain the results of respondents' answers. The variables found in this study were turnover intention measured using indicators developed by Mobley et al. (1978), cited from (Ibrahim, 2017), person-organization fit variable was measured using indicators developed by Febe (2016), job satisfaction variable was measured using indicators developed by Luthans (2006) cited from Witasari (2009), and organizational commitment variable using indicators developed by Meyer and Allen (1997) cited from Sukamto et al., (2014).

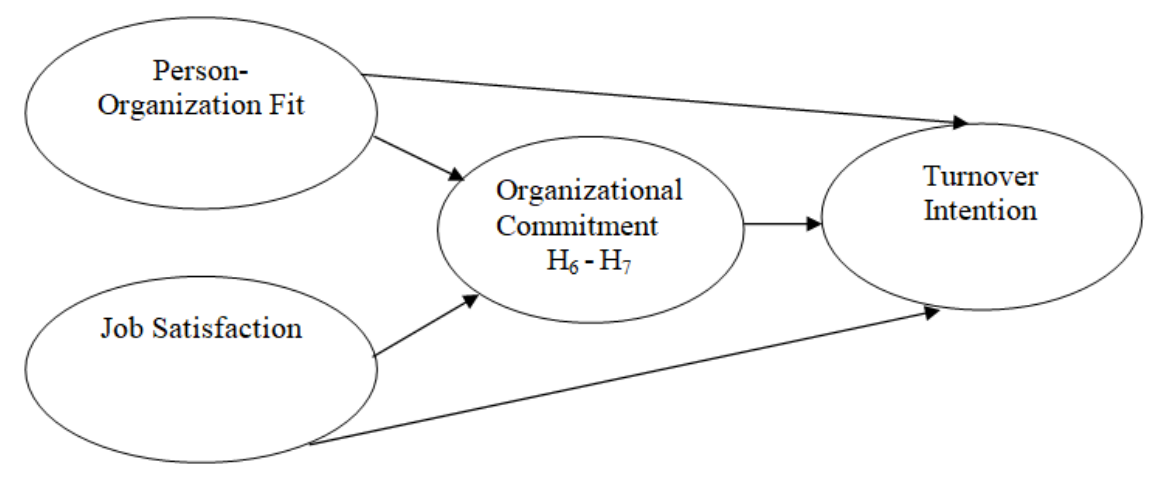

Figure 1 - Hypothesis model

The weighting of each variable was using a five-level scale (Likert scale) consisting of strongly agree, agree, sufficient, disagree, and strongly disagree. The result of instrument reliability test showed that all items in research variable were reliable because Cronbach's Alpha was above 0.6, while the result of validity test of research instrument by using correlation technique of Product Moment Pearson showed that four items on job satisfaction variable were invalid because the value of $r$ count was less than 0.3 , so it was removed from the analysis, while the other research variable items used were valid. Data analysis in this research was using Partial Least Square (PLS). 
The research hypotheses are formulated as follows:

$\mathrm{H} 1$ : Person-organization fit significantly affects employee turnover intention.

$\mathrm{H} 2$ : Job satisfaction significantly affects employee turnover intention.

H3: Person-organization fit significantly affects the organizational commitment of employees.

$\mathrm{H} 4$ : Job satisfaction significantly affects the organizational commitment of employees.

H5: Organizational commitment significantly affects employee turnover intention.

H6: Person-Organization Fit significantly affects turnover intention with the organizational commitment as the mediating variable.

\section{RESULTS AND DISCUSSION}

In accordance with the hypothesis that has been formulated, then in this study the analysis of inferential statistical data measured by using SmartPLS 3.0 software ranging from model measurement (outermodel), model structure (inner model) and hypothesis testing (Ghozali, 2014). Based on the model measurement (outermodel) namely the test of discriminant validity and composite reliability shows that all variables are valid (value $\sqrt{ }$ AVE> 0.5 ) and reliable (CR value> 0.7).

Table 1 - Value of Square Root of Average Variance Extract (AVE) and Composite Reliability (CR) Latent Variable Research

\begin{tabular}{|c|c|c|c|c|}
\hline Variable & AVE & $\sqrt{ }$ AVE & CR & Explanation \\
\hline Person-Organization Fit & 0.423 & 0.650 & 0.927 & Valid \& Reliable \\
\hline Job Satisfaction & 0.398 & 0.631 & 0.788 & Valid \& Reliable \\
\hline Organizational Commitment & 0.410 & 0.640 & 0.939 & Valid \& Reliable \\
\hline Turnover Intention & 0.439 & 0.662 & 0.774 & Valid \& Reliable \\
\hline
\end{tabular}

Source: Data that have been processed by using statistical tool.

Assessment towards structural model or inner model is done to see the relationship between construct, significance value and R-Square research model.

Table 2 - R-Square Value of Dependent Construction

\begin{tabular}{|c|c|}
\hline Variable & $R$-Square \\
\hline Organizational Commitment $(\mathrm{Z})$ & 0.639 \\
\hline Turnover Intention (Y) & 0.357 \\
\hline
\end{tabular}

Source: Data that have been processed by using SmartPLS 3.0

Q-Square value can be obtained by the formula:

$$
\begin{aligned}
& Q^{2}=1-\left(1-R_{1}{ }^{2}\right)\left(1-R_{2}{ }^{2}\right) \ldots . .\left(1-R p^{2}\right) \\
& Q^{2}=1-\left(1-0.639^{2}\right)\left(1-0.357^{2}\right)=0.484
\end{aligned}
$$

Q-Square value is known to be 0.484 or $48.4 \%$ for person-organization fit and job satisfaction as independent variables that effect the turnover intention through organizational commitment. Based on the results of this calculation also gives the meaning that there are still $51.6 \%$ other variables that can affect the turnover intention of marketing funding employees at PT. Bank NTB outside the model that is not examined. For example leadership, compensation, organizational culture, stress, burnout, and work environment.

Furthermore, hypothesis testing can be seen from the value of path coefficient and significant $p$-value $(\alpha=0.05)$ on the relationship between the variables.

Based on table 3 , the relationship of person-organization fit with turnover intention is not significant (coefficient $=-0.092$, $p$-value $=0.544$ ) so that hypothesis 1 that states personorganization fit significantly affects the turnover intention is rejected. Based on the distribution of respondents' answers, the value of statement items on compensation, the similarity with the company, and compatibility with organizational culture have low value. This 
is because the compensation given by the organization is deemed incompatible with the workload given. In addition, employees feel that the organization has nothing in common with them and the organizational culture is incompatible with employees so the employees feel they have no suitability with the organization. Although the employees generally feel unsuited to the organization, the statement items on bonuses and facilities have a high value that affecting the low turnover intention. The research result on hypothesis 1 is not in line with the research conducted by Liu et al. (2010) on the Chinese public sector and Hassan (2012) in the top five commercial banks in the Pakistan city which states that person-organization fit has a significant negative effect on turnover intention. However, the results of this study are in line with research conducted by Latif and Bashir (2013) with positive and insignificant results between person-organization fit and turnover intention relationship.

Table 3 - Hypothesis Testing Result

\begin{tabular}{|c|c|c|c|c|c|}
\hline No & Relationship between Variables & $\begin{array}{c}\text { Path } \\
\text { Coefficient }\end{array}$ & $\begin{array}{c}\text { T- } \\
\text { statistics }\end{array}$ & $\begin{array}{c}p \\
\text { value }\end{array}$ & Conclusion \\
\hline 1. & Person-Organization Fit (X1) $\rightarrow$ Turnover Intention (Y) & -0.092 & 0.607 & 0.544 & $\begin{array}{c}\text { Not } \\
\text { Significant }\end{array}$ \\
\hline 2. & Job satisfaction (X2) $\rightarrow$ Turnover Intention (Y) & -0.112 & 0.770 & 0.442 & $\begin{array}{c}\text { Not } \\
\text { Significant }\end{array}$ \\
\hline 3. & $\begin{array}{c}\text { Person-Organization Fit (X1) } \rightarrow \text { Organizational } \\
\text { Commitment (Z) }\end{array}$ & 0.436 & 4.011 & 0.000 & Significant \\
\hline 4. & Job satisfaction (X2) $\rightarrow \begin{array}{c}\text { Organizational Commitment } \\
(Z)\end{array}$ & 0.436 & 3.834 & 0.000 & Significant \\
\hline 5. & $\begin{array}{c}\text { Organizational Commitment (Z) } \rightarrow \text { Turnover Intention } \\
(Y)\end{array}$ & -0.456 & 2.985 & 0.003 & Significant \\
\hline 6. & $\begin{array}{c}\text { Person-Organization Fit (X1) } \rightarrow \text { Organizational } \\
\text { Commitment (Z) } \rightarrow \text { Turnover Intention (Y) }\end{array}$ & 0.199 & & $\begin{array}{c}\text { Full } \\
\text { Mediation }\end{array}$ \\
\hline 7. & $\begin{array}{c}\text { Job satisfaction (X2) } \rightarrow \text { Organizational Commitment } \\
(Z) \rightarrow \text { Turnover Intention (Y) }\end{array}$ & 0.199 & $\begin{array}{c}\text { Full } \\
\text { Mediation }\end{array}$ \\
\hline
\end{tabular}

Source: Data that have been processed by using SmartPLS 3.0

Based on table 3 , the relationship of job satisfaction with turnover intention is not significant (coefficient $=-0.112, p$-value $=0.442$ ) so that hypothesis 2 that expresses job satisfaction has significant effect to turnover intention is rejected. Based on the distribution of respondents' answers of statement items, promotion policy has the lowest value. Existing promotional policy does not fully make employees feel very satisfied. Marketing funding employees feel an injustice in terms of promotion. Most of them feel that they are not getting the promotion even after working optimally and exceeding the target given by the organization. They complain about the promotion given to other employees with low standard. But the employees feel that the job is interesting and it is fun to learn new things. This causes turnover intention of low marketing funding employees. The results of the research on hypothesis 2 are not in line with the research conducted by Tnay et al., (2013) and Ghandi et al., (2017) which states that job satisfaction has a significant negative effect on turnover intention. However, this study is in line with research conducted by Octaviani (2015) which shows insignificant results on the relationship of job satisfaction and turnover intention.

The test result on the coefficient of the parameter between person-organization fit to organizational commitment shows the coefficient value of 0.436 and value of $p$-value of $0.000<0.05$ so that the influence is significant. Thus, hypothesis 3 that states personorganization fit has significant effect on organizational commitment is accepted. The existence of value conformity between employees and the organization causes the employees to keep committing to the organization in the long term. The commitment will also increase if the employees get tasks that require responsibility and growth opportunities. Hypothesis 3 supports the research conducted by Ahmadi et al. (2014), and Khaola and Sebotsa (2015).

The test result on the parameter coefficient between job satisfaction to organizational commitment shows the coefficient value of 0.436 and $p$-value of $0.000<0.05$ so that the 
influence is significant. Thus, hypothesis 4 that states job satisfaction has a significant effect on organizational commitment is accepted. The work involved plays an important role in how satisfied an employee is to his/her work which, in turn, affects the organizational commitment. The employee's sense of duty will make the job to be more interesting. In addition, with an interesting job, an employee feels an opportunity to learn new things and gain responsibility and challenge for his/her work. When the work is traversed with sincerity and full of responsibility and well-resolved will increase the organizational commitment of the employee. Hypothesis 4 supports the research conducted by Sutanto and Gunawan (2013), as well as Yamazakia and Petchdee (2015).

The test result on the parameter coefficient between organizational commitment to turnover intention shows the coefficient value of -0.456 and $p$-value of $0.003<0.05$ so that the effect is significant. Thus, hypothesis 5 which states organizational commitment has a significant effect on intention turnover is rejected. The desire of an employee to continue to work for an organization because he/she agrees with the organization and indeed wants to do his/her job. In this case, the employees see the organization as a place where they feel important and competent to remain in the organization. In addition, the employees feel comfortable, secure, and feel the other benefits while in this organization. They also think that they do not get these benefits from other organizations. These kind of feelings make the employees feel at home in the organization and lower the turnover intention. Hypothesis 5 supports the research conducted by Jehanzeb et al., (2013).

The amount of indirect effect of a variable is obtained through the result of multiplication of path coefficient (beta) between the direct influence of person-organization fit (or job satisfaction) to organizational commitment (0.436) with direct influence of organizational commitment to turnover intention (0.456).

Person Organization Fit $(X 1) \rightarrow$ Organizational Commitment $(Z) \rightarrow$ Turnover Intention $(Y)=0.436 \times 0.456=0.199$

Job Satisfaction $(X 2) \rightarrow$ Organizational Commitment $(Z) \rightarrow$ Turnover Intention $(Y)=0.436 \times 0.456=0.199$

Comparison of indirect influence, both person-organization fit and job satisfaction, with turnover intention through organizational commitment with direct influence between personorganization fit/ job satisfaction toward turnover intention obtained results $0.199>0.092$. It can be stated that organizational commitment serves as full mediation. This means that both person-organization fit and job satisfaction are not able to significantly influence turnover intention without going through organizational commitment. The compatibility or suitability between the employee and the organization strongly determines how satisfied and bound the employee is with the organization he/she works for. In turn, the suitability will surely increase the organizational commitment of employees that will impact on the performance of employees and organization. The employees who are committed to maintaining commitment have a sense of loyalty to the organization that will undermine employees' intention to migrate to the workplace that impacts the decline in the employee turnover intention. Similarly, job satisfaction has no significant effect on turnover intention. Hence, the need for mediation of organizational commitment to job satisfaction can influence turnover intention significantly. This means that the more satisfied the marketing funding employees with their organization (PT Bank NTB), the higher their commitment to the organization that will ultimately lead to lower turnover intention or the willingness of employees to get out of the organization where they work now. The employees who are satisfied with the organization will find the job interesting, they are happy to learn new things, satisfied with salary and benefits, satisfied with the attitude of superiors in terms of providing support and motivation, satisfied with the attitude of other colleagues who support each other, and satisfied with the existing promotion policy. The result will have an impact on the organizational commitment they hold. An employee, who has the high sense of commitment, will tend to have a sense of loyalty to the organization, works maximally and will stay in the organization in the long-term. There will be no tendency for turnover intention to appear in the employees' minds which will affect the employee turnover. 


\section{CONCLUSION}

Based on the above description, it can be deduced as follows: person-organization fit has no significant effect on turnover intention, job satisfaction has no significant effect on turnover intention, person-organization fit has significant effect on organizational commitment, job satisfaction has significant effect on turnover intention, organizational commitment influences significant to turnover intention, person-organization fit can influence turnover intention with mediation of organizational commitment, job satisfaction can influence turnover intention with mediation of organizational commitment.

There is a limitation in this study. First, the factors affecting turnover intention in this study consist of only three variables, namely person-organization fit, job satisfaction, and organizational commitment. Meanwhile, there are many other factors affecting turnover intention. Second, the sample used in this study is only done on marketing funding employees of PT. Bank NTB so that the results obtained may make a difference if done on different types of organization such as in BUMD, the government bank, private bank, or the finance company.

\section{REFERENCES}

1. Ahmadi, S. A. A., Mohammadpour, B., Rajabi, M., \& Baghbani, F. (2014). Effect of person-organization fit on organizational commitment. International Journal of Information Technology and Management Studies, 1, 33-43.

2. Alniacik, E., Alniacik, U., Erat, S., \& Akcin, K. (2013). Does person-organization fit moderate the effects of affective commitment and job satisfaction on turnover intentions?. Social and Behavioral Sciences, 274-281.

3. Booth, S., \& Hamer, K. (2007). Labour turnover in the retail industry (Predicting the role of individual, organizational, and environmental factors). International Journal of Retail and Distribution Management, 35 (4), 289-307.

4. Donald, P.M. \& Pandey, S.K. (2007). The Ties that Blind: Social Networks PersonOrganization Fit and Turnover Intention. SSRN: New York, USA.

5. Faloye, D. O. (2014). Organizational commitment and turnover intentions: evidence from nigerian paramilitary organization. International Journal of Business and Economic Development (IJBED), 2 (3), 23-34.

6. Febe S.P., \& Valentina. (2016). Person-organization fit karyawan BPR Restu Artha Makmur. Universitas Katolik Soegijapranata Semarang.

7. Ghandi, P., Hejazi, E., \& Ghandi, N. (2017). A Study on the relationship between resilience and turnover intention: with an emphasis on the mediating roles of job satisfaction and job stress. Journal Bulletin de la Societe Royale des Sciences de Lievege, 189-200.

8. Ghozali, I. (2014). Partial Least Squares Konsep, Metode dan Aplikasi Menggunakan Program Warp PLS 4.0. Badan Penerbit Universitas Diponegoro: Semarang.

9. Hassan, M. U. (2012). The relationship between person-organization fit, person-job fit and turnover intention in banking sector of pakistan: the mediating role of psychological climate. International Journal of Human Resource Studies, 2 (3), 172-188. http://dx.doi.org/10.5296/ijhrs.v2i3.2286

10. Ibrahim, I. D. K. (2017). Pengaruh Stres Kerja terhadap Turnover Intentions yang Dimediasi oleh Burnout. Unpublished Thesis. Master's Program in Management, Universitas Mataram.

11. Jehanzeb, K., Raheed, A., \& Rasheed, M. F. (2013). Organizational commitment and turnover intentions: impact of employee's training in private sector of saudi arabia. International Journal of Business and Management, 8 (8), 79-90. http://dx.doi.org/10.5539/ijbm.v8n8p79

12. Khaola, P. P. \& Sebotsa, T. (2015). Person-organization fit, organizational commitment and organizational citizenship behaviour. Danish Journal of Management and Business Sciences, 67-74. 
13. Kristof-Brown, A.L., Zimmerman, R.D., \& Johnson, E. C. (2005). Consequences of individuals' fit at work: a meta-Analysis of person- job, person-organization, persongroup, and person-supervisor fit. Personnel Psychology, 58, 281-342.

14. Kristof, A. L. (1996). Person-organization fit: an integrative review of its conceptualizations, measurement and implications. Personnel Psychology, 49 (1), 1-49.

15. Latif, A., \& Bashir, U. (2013). Person-organization fit, job satisfaction and turnover intention: an empirical study in the context of pakistan. Global Advance Research Journal of Management and Business Studies,2 (7), 384-388.

16. Liu, B., Liu, J., \& Hu, J. (2010). Person-organization fit, job satisfaction, and turnover intention: an empirical study in the chinese public sector. Social Behavior and Personality, 615-626.

17. Luthans. (2006). Manajemen Personalia. Jakarta: PT. Erlangga.

18. Meyer, J., \& Allen, N. (1991). A three component conceptualization of organizational commitment. Human Resource Management Review,1 (1), 61-90.

19. Meyer, J. P., \& Allen, N. J. (1997). Commitment In The Workplace: Theory, Research, and Application. Thousand Oaks, CA: Sage Publication, Inc.

20. Mobley, W., Horner, S., \& Hollingworth, A. (1978). An Evaluation of Precursors of Hospital Employee Turnover. Journal of Applied Psychology, 63 (4), 408-414.

21. Motowildo, S.J. (1983). Predicting sales turnover from pay satisfaction and expectation. Journal of Applied Psychology, 69, 57-166.

22. Mowday, R. T., Porter, L. W., \& Steers, R. M. (1982). Employee-Organisation Linkages. New York, NY: Academic Press.

23. Mobley, W. H. (1986). Pergantian Karyawan: Sebab, Akibat dan Pengendaliannya. Jakarta: PT. Pustaka Binaman Pressindo.

24. Octaviani, H. (2015). Person-organization fit, kepuasan kerja, dan turnover intention: studi empiris pada karyawan generasi $\mathrm{Y}$ industri perbankan di indonesia. Jurnal Manajemen, 12 (2), 111-128.

25. Robbins, S.P, \& Judge. (2007). Perilaku Organisasi, Jakarta: Salemba Empat.

26. Robbins, S. P. \& Judge, T. A. (2009). Organizational Behavior 13th Edition. London: Pearson International Edition.

27. Robbins, S. P. (2006). Perilaku Organisasi. Edisi Kesepuluh. PT Indeks : Kelompok Gramedia.

28. Roelen, C.A.M. (2008). Which Work Factors Determine Job Satisfaction. International Journal of Industrial Ergonomics.

29. Roseman, E. (1981). Managing Turnover: A Positive Approach. New York: Amacom.

30. Saeed, I. (2014). The relationship of turnover intention with job satisfaction, job performance, leader member exchange, emotional intelligence and organizational commitment. International Journal of Learning \& Development, 4 (2).

31. Saeka, I. P. A. P., \& Suana, I. W. (2016). Pengaruh kepuasan kerja, komitmen organisasional dan stres kerja terhadap turnover intention karyawan PT. Indonusa Algaemas Prima Bali. E-Jurnal Manajemen Unud, 5 (6), 3736-3760.

32. Sukamto, H., Junarto, Y., Kaihatu, T., \& Kartika, E. W. (2014). Analisa pengaruh komitmen afektif, komitmen normatif, dan komitmen berkelanjutan terhadap turnover intention di Dragon Star Surabaya. Jurnal Hospitality dan Manajemen Jasa, 2, 466-478.

33. Sutanto, E. M., \& Gunawan, C. (2013). Kepuasan kerja, komitmen organisasional dan turnover intentions. Jurnal Mitra Ekonomi dan Manajemen Bisnis, 4 (1), 76-88.

34. Tnay, E., Othman, A. E. A., Siong, H. C., \& Lim, S. L. O. (2013). The influances of job satisfaction and organizational commitment on turnover intention. Social and Behavioral Sciences, 201-208. http://doi: 10.1016/j.sbspro.2013.10.223

35. Witasari, L. (2009). Analisis Pengaruh Kepuasan Kerja dan Komitmen Organisational terhadap Turnover Intentions (Studi Empiris pada Novotel Semarang). Unpublished Thesis. Faculty of Economics, UNDIP.

36. Yamazakia, Y., \& Petchdee, S. (2015). Turnover intention, organizational commitment, and specific job satisfaction among production employees in Thailand. Journal of Business and Management, 4 (4), 22-38. 